\title{
Kreowanie sieciowych produktów turystycznych w województwie mazowieckim
}

\section{Barbara Dymna}

\begin{abstract}
STRESZCZENIE
Celem artykułu jest zdefiniowanie pojęć produkt turystyczny i sieciowy produkt turystyczny oraz nakreślenie historii ich kreowania i komercjalizacji na Mazowszu wraz z propozycjami nowych produktów w peryferyjnych obszarach województwa mazowieckiego. W województwie mazowieckim występują duże dysproporcje w wykorzystaniu potencjału turystycznego. Sieciowe produkty turystyczne, zwłaszcza markowe, umożliwiłyby zintegrowanie znanych atrakcji województwa z walorami obszarów dotychczas niewykorzystanych. Wspieranie tworzenia i promowania produktów turystycznych stanowi jeden z elementów polityki rozwoju regionu, jaką prowadzi samorząd województwa mazowieckiego, czego potwierdzeniem są zapisy w dokumentach strategicznych, planistycznych i programowych województwa. W Planie zagospodarowania przestrzennego województwa mazowieckiego i Strategii rozwoju województwa mazowieckiego do roku 2030 Innowacyjne Mazowsze wskazuje się możliwości ożywienia społeczno-gospodarczego subregionów: siedleckiego, radomskiego, płockiego, ciechanowskiego i ostrołęckiego (uznanych za obszary problemowe województwa mazowieckiego) poprzez rozwój turystyki, w tym wykreowanie i skomercjalizowanie sieciowych produktów turystycznych. Usystematyzowane prace nad wykreowaniem, promowaniem i funkcjonowaniem sieciowych produktów turystycznych wdrożyła Mazowiecka Regionalna Organizacja Turystyczna (MROT). W artykule przedstawiono proces powstawania produktów turystycznych na przestrzeni lat 2008-2017 oraz problemy związane z ich wdrażaniem. Artykuł zawiera również krótką charakterystykę dotychczas niewykorzystanych walorów kulturowych i przyrodniczych, peryferyjnych obszarów regionu, na których można oprzeć produkty turystyczne zaproponowane przez MBPR w Warszawie. Możliwości rozwoju produktów turystycznych wymagają jednak podjęcia szeregu działań ze strony administracji samorządowej województwa, w zakresie m.in. rozbudowy infrastruktury technicznej (szczególnie komunikacyjnej i teleinformatycznej), pomocy finansowej, promocji produktów turystycznych oraz nawiązania współpracy z samorządami sąsiednich województw. Słowa kluczowe: produkt turystyczny, sieciowy produkt turystyczny, dokumenty strategiczne, planistyczne i programowe województwa
\end{abstract}

\section{Wprowadzenie}

Celem artykułu jest nakreślenie procesu powstawania produktów turystycznych w województwie mazowieckim oraz przedstawienie propozycji nowych produktów dla peryferyjnych części regionu wykreowanych dzięki wykorzystaniu walorów przyrodniczych, kulturowych i historycznych.

$\mathrm{Na}$ przestrzeni ostatnich lat nastąpiły zmiany w stylu życia społeczeństw będące wynikiem gwałtownego postępu cywilizacyjnego. Spowodował on wzrost zamożności i wydłużenie życia mieszkańców krajów wysoko rozwiniętych. Nie ominęło to także turystyki, której rozwój wynika z ww. czynników, a ponadto ze zwiększenia ilości czasu wolnego, wzrostu liczby ludności miejskiej, wzrostu poziomu wykształcenia społeczeństwa, poprawy świadomości zdrowotnej oraz zwrotu w kierunku zdrowego trybu życia. Do rozwoju turystyki przyczyniło się także upowszechnianie środków transportu, w tym dalekiego zasięgu, co spowodowało skrócenie dystansu, czasu dojazdu i zmniejszenie kosztów podróży oraz zwiększenie dostępności zróżnicowanej oferty turystycznej 
i kształtowanie się nowych form spędzania czasu wolnego. Jednak postęp cywilizacyjny okupiony wyczerpującą pracą i szybkim tempem życia wymusza potrzebę regeneracji sił fizycznych i psychicznych. Współczesny turysta chce jak najefektywniej wykorzystać czas przeznaczony na wypoczynek, doświadczając przy tym dużej dawki wrażeń. Ma też mniej czasu na samodzielne wyszukiwanie atrakcji i organizowanie sobie pobytu, dlatego oczekuje przygotowanych, kompleksowych ofert turystycznych. Zbiór tych świadczeń nazywany jest produktem turystycznym. R. Łazarek [2004, s. 50] definiuje produkt turystyczny "jako jedność walorów turystycznych w miejscu docelowym podróży oraz komplementarnych dóbr i ustug, które umożliwiaja czasowa zmianę stałego środowiska, a także umożliwiaja i uprzyjemniaja pobyt w miejscu docelowym podróży".

W odróżnieniu od produktów prostych, tj. pojedynczej usługi (podróż, nocleg, zwiedzanie), różnorodne potrzeby współczesnego turysty zaspokaja sieciowy produkt turystyczny. Sieciowy produkt turystyczny wg Polskiej Organizacji Turystycznej to gotowa do sprzedaży spakietyzowana oferta, wykorzystująca rozproszoną strukturę podmiotów, atrakcji, miejsc, punktów obsługi, obiektów, funkcjonująca jakojedna spójna koncepcja, mająca wspólny, wiodący silny wyróżnik (markę) produktu. Sieciowy produkt turystyczny tworzy wymierne korzyści nie tylko dla jego konsumentów, ale także podmiotów zaangażowanych w utworzenie i funkcjonowanie produktów - przedsiębiorstw i organizacji turystycznych wspieranych przez władze lokalne i regionalne. Interesariusze zaangażowani w tworzenie, urynkowienie i promocję sieciowego produktu turystycznego odnoszą większe korzyści niż przedsiębiorstwa samodzielnie sprzedające proste produkty turystyczne. Większe korzyści to: obniżenie kosztów promocji, rozwój własnych prostych produktów turystycznych na bazie usług świadczonych przez partnerów, wzrastające zyski, a tym samym większe wpływy do budżetów samorządów lokalnych. Mieszkańcy obszaru, na którym rozwija się produkt również odnoszą korzyści: bezpośrednie w postaci nowych miejsc pracy, możliwości zdobycia nowych umiejętności i zbycia lokalnych wyrobów oraz pośrednie - związane z poprawą jakości życia poprzez rozbudowę infrastruktury turystycznej i paraturystycznej, odnowę zabudowy zabytkowej, a także kształtowanie postawy przedsiębiorczości. Przekładając to na potrzeby rozwoju turystyki na obszarze regionu, można powiedzieć, że cechą i jednocześnie siłą produktu sieciowego jest połączenie w jedno wielu usług i atrakcji oraz współpraca pomiędzy podmiotami działającymi w branży turystycznej.

\section{Historia kreowania produktów turystycznych w województwie mazowieckim}

Produkty turystyczne stanowią istotne czynniki rozwoju turystyki w danym regionie turystycznym. Kreowanie i rozwój produktów turystycznych, zwłaszcza innowacyjnych, jest podstawą działania nie tylko przedsiębiorstw turystycznych, ale także innych instytucji odpowiedzialnych za rozwój turystyki. Na przestrzeni ostatnich lat w województwie mazowieckim za sprawą lokalnych organizacji turystycznych nastąpiło znaczne ożywienie w działalności turystycznej. Ich działalność przyczyniła się do integracji społeczności lokalnych, jednostek samorządu terytorialnego, placówek kultury, przedsiębiorstw nie tylko 
branży turystycznej i organizacji pozarządowych w działaniach na rzecz rozwoju turystyki, w tym do tworzenia produktów turystycznych oraz ich promocji. Pod przewodnictwem Kurpiowskiej Organizacji Turystycznej powstały pierwsze produkty turystyczne: Brama na Kurpie i Bursztynowy Pierścień Kurpiowski, mające na celu wypromowanie walorów przyrodniczych Puszczy Kurpiowskiej oraz tradycji folklorystycznych Kurpiowszczyzny, a także stworzenie systemu informacji turystycznej o tym regionie. Następnie Lokalna Organizacja Turystyczna Mazowsze Chopina zrealizowała m.in. projekt Program rozwoju i promocji produktu turystycznego Mazowsze Chopina, który zakładał wypromowanie oferty turystycznej zachodniego Mazowsza, w szczególności miejsc związanych z życiem i twórczością Fryderyka Chopina, a Lokalna Organizacja Turystyczna Cud nad Wista projekt Bitwa Warszawska 1920 - Cud nad Wisła, mający na celu przybliżenie tego wydarzenia historycznego.

Jednak bardziej usystematyzowane działania na rzecz rozwoju produktów turystycznych na Mazowszu podjęła powołana w 2006 r. Mazowiecka Regionalna Organizacja Turystyczna (MROT) z siedzibą w Warszawie. Jednym z założycieli organizacji jest samorząd województwa mazowieckiego, a jej głównym celem statutowym jest kreowanie i promowanie atrakcyjnego wizerunku regionu. Członkami MROT są organy administracji rządowej i samorządowej, Polska Izba Turystyki, podmioty gospodarcze, a także organizacje pozarządowe działające w sektorze turystyki, w tym lokalne organizacje turystyczne. MROT aktywnie działa na rzecz rozwoju turystyki m.in. poprzez integrację różnych środowisk oraz wszelkich inicjatyw turystycznych i proturystycznych, w tym związanych z rozwojem produktów turystycznych na Mazowszu.

Podstawowym dokumentem na jakim organizacja opierała swoją działalność była Strategia rozwoju turystyki województwa mazowieckiego na lata 2007-2013 przyjęta przez Sejmik Województwa Mazowieckiego. Celem nadrzędnym postawionym w tym dokumencie było zwiększenie znaczenia gospodarczego turystyki w regionie, które mogłoby być osiągnięte m.in. przez "rozwój oferty produktowej integrujacej walory turystyczne regionu mazowieckiego dostosowanej do potrzeb odbiorców".

Na potrzeby tej organizacji w 2008 r. powstał Program rozwoju produktów turystyki aktywnej i kulturowej w województwie mazowieckim [Majewska, Telniuk, Broma i in. 2008], jako dokument wdrożeniowy ww. Strategii. Program zawierał koncepcję 44 produktów turystycznych wraz z harmonogramami ich wdrażania i źródłami finansowania. Wśród nich było:

- 8 produktów wiodących, tzw. pereł, opartych na wyróżnikowych walorach województwa mazowieckiego o największym potencjale rozwojowym,

- 19 ponadlokalnych produktów liniowych lub sieciowych integrujących wybrane, wielkoobszarowe atrakcje tematyczne,

- 17 produktów miejsca - wykorzystujących jeden walor lub atrakcję, ale skupiających więcej dóbr i usług.

Program zrealizowano tylko częściowo ze względu na napotkane przeszkody w postaci barier instytucjonalnych, zbyt dużej liczby zaproponowanych produktów oraz braku koordynacji i współpracy pomiędzy podmiotami zaangażowanymi w produkt. W trakcie 
tworzenia, wdrażania i monitorowania rozwoju produktów turystycznych nasunął się wniosek, że dla rozwoju turystyki w regionie większe znaczenie mogą mieć produkty sieciowe niż produkty miejsca. Produkty sieciowe charakteryzują się komplementarnościa zdolnością integracji pomiędzy różnymi partnerami rynku, zdolnością do przedłużania sezonu turystycznego, a nawet pojedynczych pobytów w regionie. Produkty sieciowe, integrując wiele składników oferty, stają się bardziej atrakcyjne dla potencjalnych turystów, którzy zgodnie z istniejącymi trendami, wybierają destynacje mogące zaspokoić wiele potrzeb podczas krótszych pobytów.

W związku z tym w 2011 r. Mazowiecka Regionalna Organizacja Turystyczna przystąpiła do opracowania projektu pn. Podnoszenie konkurencyjności turystycznej Mazowsza poprzez wdrażanie sieciowych produktów turystycznych, dofinansowanego przez Ministerstwo Sportu i Turystyki. Głównym celem projektu było podniesienie konkurencyjności turystycznej województwa mazowieckiego poprzez kreację i rozwój sieciowych produktów turystycznych. Projekt realizowano metodą partycypacyjno-ekspercką. Efektem działań MROT i organizowanych przez tę instytucję seminariów, spotkań warsztatowych z przedstawicielami lokalnych organizacji turystycznych i innych interesariuszy rynku turystycznego było zdefiniowanie kluczowych produktów turystycznych przeznaczonych do komercjalizacji oraz opracowanie dokumentu wdrożeniowego pt. Program rozwoju sieciowych produktów turystycznych województwa mazowieckiego. Lista produktów proponowana do wdrażania ulegała wielokrotnie zmianom, by ostatecznie zamknąć się liczbą 25 produktów o największym potencjale rozwojowym. Ostatecznie do wdrażania przeznaczono 16 produktów turystycznych najbardziej zaawansowanych w rozwoju, które usystematyzowano w 4 tzw. marki parasolowe (rodzinne). Ich krótką charakterystykę przedstawia tabela 1.

Przy ich wyborze kierowano się potrzebą promocji bogatych walorów turystycznych województwa mazowieckiego, przede wszystkim walorów kulturowych, zwłaszcza obszarów peryferyjnych regionu i tym samym wyprowadzenie ruchu turystycznego z Warszawy w stronę tych obszarów. W ramach ww. produktów przystąpiono do wypracowania i skomercjalizowania ofert produktowych. Za komercjalizację produktów odpowiedzialni są liderzy wspierani przez koordynatora ds. rozwoju produktów turystycznych działającego w strukturach MROT. Wynikiem prac liderów i koordynatora nad wdrażaniem 16 produktów turystycznych było stworzenie komercyjnych pakietów letnich i zimowych ofert produktowych gotowych do sprzedaży przez biura podróży czy punkty informacji turystycznej. W celu wypromowania tych ofert wydano Katalog Produktowy Mazowsze Lato-Zima 2013-2014 w języku polskim i angielskim oraz ulotki, za pomocą których rozpowszechniano o nich informację. Informacje o pakietach umieszczono również na portalu turystycznym województwa mazowieckiego www.mazowsze.travel. 
Tabela 1. Sieciowe produkty turystyczne przeznaczone do komercjalizacji

\begin{tabular}{|c|c|}
\hline Produkt & Główna atrakcja \\
\hline \multicolumn{2}{|r|}{ MARKA PARASOLOWA: HISTORIA } \\
\hline Szlak Książąt Mazowieckich & $\begin{array}{l}\text { zabytki z okresu Księstwa Mazowieckiego (zamki, dwory, grodziska } \\
\text { i kościoły) oraz kultura i obyczaje średniowiecza }\end{array}$ \\
\hline Wielki Gościniec Litewski & $\begin{array}{l}\text { najważniejszy w okresie Rzeczypospolitej Obojga Narodów szlak } \\
\text { drogowy łączący jej stolice: Warszawę i Wilno, w tym szczególnie } \\
\text { miejsca na szlaku związane z postaciami historycznymi }\end{array}$ \\
\hline Industrialne Mazowsze & $\begin{array}{l}\text { obiekty związane z dziedzictwem przemysłowym regionu (włó- } \\
\text { kiennictwem, hutnictwem, kolejnictwem), w tym będąca pomni- } \\
\text { kiem historii osada fabryczna w Żyrardowie położona na trasie } \\
\text { historycznej kolei warszawsko-wiedeńskiej }\end{array}$ \\
\hline $\begin{array}{l}\text { Szlakiem Frontu Wschodniego I Wojny } \\
\text { Światowej na Mazowszu }\end{array}$ & $\begin{array}{l}\text { pozostałości działań wojennych z okresu I wojny światowej i rekon- } \\
\text { strukcje historyczne „Bzura - Rawka 1914-1915” }\end{array}$ \\
\hline Szlak Cudu nad Wisłą & $\begin{array}{l}\text { miejsca i inscenizacje historyczne związane z przebiegiem walk } \\
\text { w ramach Bitwy Warszawskiej } 1920 \text { r., w tym rekonstrukcja bitwy }\end{array}$ \\
\hline \multicolumn{2}{|c|}{ MARKA PARASOLOWA: SMAKI I TRADYCJE } \\
\hline Szlak folkloru i smaków Mazowsza & regionalne dziedzictwo kulinarne \\
\hline Legendy i Baśnie Mazowsza & miejsca w regionie związane z lokalnymi legendami i baśniami \\
\hline Śladami Nadbużańskich Tajemnic & $\begin{array}{l}\text { walory kulturowe terenów nadbużańskich, w tym twórczość arty- } \\
\text { stów ludowych }\end{array}$ \\
\hline \multicolumn{2}{|c|}{ MARKA PARASOLOWA: KULTURA I SZTUKA } \\
\hline Mazowsze na filmowo & $\begin{array}{l}\text { zabytki, krajobrazy, miasta i miasteczka będące planami produkcji } \\
\text { filmowych i telewizyjnych }\end{array}$ \\
\hline Mazowsze Chopina & miejsca związane z życiem i twórczością Fryderyka Chopina \\
\hline Skarbiec Mazowiecki & $\begin{array}{l}\text { zabytkowe obiekty sakralne, miejsca związane z życiem i działalno- } \\
\text { ścią polskich świętych i błogosławionych }\end{array}$ \\
\hline Mazowiecki Szlak Literacki & $\begin{array}{l}\text { miejsca w regionie związane z wybitnymi polskimi literatami róż- } \\
\text { nych epok }\end{array}$ \\
\hline $\begin{array}{l}\text { W kręgu żydowskiego dziedzictwa na } \\
\text { Mazowszu }\end{array}$ & zabytki i kultura żydowska \\
\hline \multicolumn{2}{|r|}{ MARKA PARASOLOWA: AKTYWNIE } \\
\hline Kajakowe Szlaki Mazowsza & rzeki regionu przydatne do uprawiania kajakarstwa \\
\hline Weekend z Termami Mszczonów & kompleks basenów termalnych w Mszczonowie \\
\hline Opowieści z Narwi & $\begin{array}{l}\text { walory przyrodnicze i kulturowe doliny Narwi wraz z Jeziorem } \\
\text { Zegrzyńskim }\end{array}$ \\
\hline
\end{tabular}

Źródło: Koncepcje sieciowych produktów turystycznych w subregionach województwa mazowieckiego, MAZOWSZE. Analizy i Studia, 7, 48, 2015 
Prace Mazowieckiej Regionalnej Organizacji Turystycznej nad produktami nie skończyły się wraz z ich wykreowaniem. W 2013 r. MROT przystąpił do realizacji projektu Promocja skomercjalizowanych pakietów turystycznych w ramach rozwoju sieciowych produktów turystycznych Mazowsza jako drugiego etapu wdrożenia wybranych sieciowych produktów turystycznych. W wyniku stałych kontaktów (m.in. warsztatów) z liderami poszczególnych produktów powstał podręcznik tworzenia sieciowych produktów turystycznych pn. Model tworzenia sieciowego produktu turystycznego [Kachniewska 2015], który stał się precedensem merytorycznym nie tylko w skali województwa, ale i kraju. W podręczniku podkreślono, że szansę na sukces mają te produkty, które uwzględniają m.in. takie elementy jak wykorzystanie tożsamości i odmienności regionalnej, w tym zasobów ludzkich, co jest bardzo istotne $\mathrm{w}$ przypadku regionu pozbawionego takich ewidentnych atrakcji jak góry czy morze. Odpowiadając na zapotrzebowanie współczesnego turysty, produkt powinien cechować się innowacyjnością i sieciowością oraz mieć markę. A przede wszystkim powinien być dostępny cenowo, informacyjnie i być gotowy do zakupu w różnych formach. Innowacyjność produktów może polegać na unikatowości tematycznej (oferty przeznaczone dla pasjonatów, tworzone na bazie specyficznych walorów), na nietypowej organizacji usług turystycznych polegających na wykorzystaniu niekonwencjonalnych środków transportu, innej niż dotychczas prezentacji obiektów, zastosowaniu nowoczesnych technologii dla uatrakcyjnienia pobytu turysty $\mathrm{w}$ danym miejscu, a także umożliwieniu bezpośredniego obcowania $\mathrm{z}$ dziedzictwem materialnym i niematerialnym obszaru poprzez uczestnictwo w różnego rodzaju warsztatach, obrzędach, spotkaniach $\mathrm{z}$ interesującymi ludźmi, a tym samym głębszym przeżywaniem wrażeń. Dla atrakcyjności produktu na rynku turystycznym jego innowacyjność ma bardzo duże znaczenie. A sieciowość produktów turystycznych poprzez integrację atrakcji i usług pozwala przyciągnąć turystów na dłużej niż może to zrobić indywidualna usługa lub obiekt. Na identyfikację markowego produktu turystycznego pozwalają: nazwa, logotyp i elementy graficzne z nim związane.

W latach 2014/2015 w MROT trwały prace nad weryfikacją dotychczasowego funkcjonowania sieciowych produktów turystycznych i umocnienie ich pozycji na rynku oraz przygotowanie do rozszerzenia sieci każdego z nich poprzez przeprowadzenie modelowych działań $\mathrm{w}$ ww. zakresie. $\mathrm{W}$ ramach tych działań $\mathrm{w}$ formie warsztatowej diagnozowano sytuacje rynkową produktu, uzupełniano w nim luki i proponowano możliwości rozszerzenia sieci każdego z produktów. W 2016 r. Mazowiecka Regionalna Organizacja Turystyczna rozpoczęła realizację kolejnego projektu pn. Rozwój, komercjalizacja i promocja sieciowych produktów turystycznych województwa mazowieckiego związanego z doskonaleniem wykreowanych produktów turystycznych. W jego ramach, działania koncentrują się na produktach najbardziej zaawansowanych w komercjalizacji, tj.: Weekend z Termami Mszczonów, Industrialne Mazowsze, Legendy i Baśnie Mazowsza, Wielki Gościniec Litewski, Szlak Folkloru i Smaków Mazowsza, Szlak Chopinowski, Szlak Bitwy Warszawskiej 1920, Szlak Książat Mazowieckich. Jest to kolejny etap wdrożenia wybranych sieciowych produktów turystycznych w województwie mazowieckim. Działania wdrożeniowe dotyczyły głównie organizacji warsztatów dla liderów poszczególnych produktów, merytorycznego 
przygotowania ofert i ich opracowania graficznego oraz druku, a także ich promocji poprzez: dystrybucję ofert do centrów i punktów informacji turystycznej, media i portale społecznościowe, publikację katalogu z produktami w językach: polskim i angielskim, promocję podczas krajowych i zagranicznych targów turystycznych oraz organizację imprez plenerowych i innych działań promocyjnych. Zakończeniem działań przewidzianych na 2017 r. była organizacja warsztatów, na których partnerzy sieciowych produktów zaprezentowali oferty przedstawicielom biur podróży i touroperatorom.

\section{Problematyka produktów turystycznych w zapisach PZPWM i SRWM oraz w innych doku- mentach wojewódzkich}

Mazowieckie Biuro Planowania Regionalnego w Warszawie jest wojewódzką samorządową jednostką organizacyjną realizującą projekty i zadania z zakresu polityki regionalnej i zagospodarowania przestrzennego. Biuro działa w szczególności na podstawie ustawy z dnia 5 czerwca 1998 r. o samorządzie województwa (Dz. U. z 2016 r. poz. 486). W ciągu kilkunastu lat działalności Biura przygotowano i zaktualizowano najważniejsze dla rozwoju województwa mazowieckiego dokumenty strategiczne i planistyczne, takie jak Strategia rozwoju województwa mazowieckiego do 2030 roku, Plan zagospodarowania przestrzennego województwa mazowieckiego, Wojewódzki program opieki nad zabytkami (kolejne edycje tego programu), Kontrakt terytorialny dla województwa mazowieckiego i inne materiały wdrożeniowe i programowe. Do zadań Biura należy także sporządzanie studiów, analiz i raportów z zakresu rozwoju regionalnego i zagospodarowania przestrzennego. W ramach działalności analitycznej Biura przeprowadzono szereg analiz możliwości rozwoju turystyki w regionie, w tym poprzez tworzenie produktów turystycznych. Problematyka turystycznego wykorzystania walorów kulturowych regionu została uwzględniona w Wojewódzkim programie opieki nad zabytkami na lata 2006-2009. Program ten wykreował pasma przyrodniczokulturowe związane z głównymi rzekami regionu. Układ pasmowy pozwala na tworzenie ponadlokalnych programów promocji i rozwoju turystyki oraz umożliwia koordynację działań o charakterze liniowym, np. związanych z wodnymi szlakami turystycznymi, czy historycznymi szlakami drogowymi i kolejowymi. W latach 2006-2008, MBPR opracowało koncepcje szlaków turystyczno-kulturowych, które obejmowały doliny najcenniejszych rzek regionu: Wisły, Bugu i Liwca, Narwi, Pilicy, Omulwi, Skrwy, Wkry i Wilgi wraz z przylegającymi gminami ocenianymi pod kątem zagospodarowania turystycznego, przez co ich zasięg terytorialny został powiększony w stosunku do pasm zdelimitowanych w wyżej wymienionym Programie. Pasma turystyczno-kulturowe znajdują się w zasięgu obszarów o najniższym poziomie rozwoju społeczno-gospodarczego wskazanych w Planie zagospodarowania przestrzennego województwa mazowieckiego. W kolejnym opracowaniu Biura przeprowadzono analizę działalności gmin położonych w tych pasmach na rzecz rozwoju turystyki. W opracowaniu Analiza działalności gmin położonych w pasmach turystycznokulturowych województwa mazowieckiego na rzecz rozwoju turystyki wykazano, że większość samorządów lokalnych docenia znaczenie rozwoju turystyki na swoim terenie. Dlatego, 
przystosowują przestrzeń gminy do rozwoju funkcji turystycznej poprzez renowację zabytków, wyznaczanie szlaków, poprawę stanu infrastruktury turystycznej. Samorządy lokalne wykazują także dużą aktywność w zakresie szerokiej promocji walorów turystycznych swoich gmin. Większość samorządów przystąpiła do lokalnych organizacji turystycznych, stowarzyszeń i lokalnych grup działania - organizacji, które są często pomysłodawcami produktów turystycznych. Pasma rzeczne oraz historyczne szlaki drogowe i kolejowe charakteryzują się dużym potencjałem do tworzenia nowych ofert w ramach istniejących produktów lub nowych sieciowych produktów turystycznych. W najnowszej edycji Wojewódzkiego programu opieki nad zabytkami na lata 2012-2015, problematyka kreowania produktów pojawia się $\mathrm{w}$ zapisach dokumentu jako jedna $\mathrm{z}$ form interwencji w celu poprawy stanu zachowania zasobów dziedzictwa kulturowego oraz wykorzystania ich na potrzeby rozwoju regionu. Problematyka tworzenia produktów turystycznych, przy wykorzystaniu walorów pasm przyrodniczo-kulturowych, znajduje odzwierciedlenie w zapisach Planu zagospodarowania przestrzennego województwa mazowieckiego oraz Strategii rozwoju województwa mazowieckiego do 2030 roku. Innowacyjne Mazowsze. Zapisy Planu odnoszą się do przedmiotowej kwestii w ustaleniach trzech polityk przestrzennych - Polityki wzrostu atrakcyjności turystycznej, Zintegrowanej polityki opieki i ochrony dziedzictwa kulturowego i dóbr kultury współczesnej oraz Polityki rozwoju i modernizacji obszarów wiejskich. Pierwsza z polityk obok działań przestrzennych, ustala także działania organizacyjne, w tym „kształtowanie rozpoznawalnej marki turystycznej województwa poprzez tworzenie wizerunkowych produktów turystycznych". Druga polityka zawiera ustalenia dotyczące tworzenia produktów turystyki kulturowej na bazie kształtowanych pasm przyrodniczo-kulturowych, sieci miast historycznych, atrakcji krajobrazowo-architektonicznych oraz tradycji historycznych, w tym ludowych. Zapisy Polityki rozwoju i modernizacji obszarów wiejskich dotyczą m.in. wykorzystania walorów krajobrazowych i kulturowych obszarów wiejskich do rozwoju turystyki, w tym agroturystyki. Ta polityka zawiera także ustalenia w zakresie promowania regionalnych produktów turystycznych. Wspieranie rozwoju turystyki kulturowej oraz tworzenie nowych produktów turystycznych jest również przedmiotem zapisów strategii rozwoju województwa (w obszarze działań dotyczących kultury i dziedzictwa). Kreowanie i promowanie produktów turystycznych ma służyć zwiększaniu wiedzy o regionie i podniesieniu jego atrakcyjności turystycznej.

Na bazie potencjału pasm rzecznych, drogowych i kolejowych można tworzyć nowe sieciowe produkty turystyczne lub nowe oferty w ramach produktów istniejących. Tej problematyki dotyczą m.in. zapisy najnowszej edycji Wojewódzkiego programu opieki nad zabytkami na lata 2012-2015. Kreowanie produktów turystycznych jest traktowane jako jedna $\mathrm{z}$ form interwencji zmierzających do osiągnięcia społecznie akceptowanej poprawy stanu zachowania zasobów dziedzictwa kulturowego oraz wykorzystania ich na potrzeby rozwoju regionu. Strategia rozwoju turystyki w województwie mazowieckim na lata 2014-2020 kładzie szczególny nacisk na funkcjonowanie produktów turystycznych, na poziom ich rozwoju i stan komercjalizacji. A w jednym z celów strategicznych zakłada spójność regionu dzięki turystyce, w tym realizację programów wspierających produkty turystyczne m.in. wykorzystujące atrakcyjność rzek Mazowsza. 


\section{Charakterystyka produktów turystycznych zaproponowanych przez Biuro}

W 2015 r. w Mazowieckim Biurze Planowania Regionalnego powstało opracowanie Koncepcje sieciowych produktów turystycznych w subregionach województwa mazowieckiego [Gadomska (red), Dymna, Gurbała i in., 2015]. Celem opracowania było wykonanie koncepcji nowych sieciowych produktów turystycznych lub ofert w ramach już istniejących 16 produktów turystycznych w obszarach peryferyjnych województwa mazowieckiego do wykorzystania ich potencjału tkwiącego w walorach środowiska kulturowego oraz przyrodniczego. Zaproponowano 7 nowych produktów oraz 10 nowych ofert w ramach już istniejących produktów turystycznych. Obszary charakteryzujące się niskim poziomem rozwoju społeczno-gospodarczego i niskim dostępem do dóbr i usług, zostały uznane w Strategii rozwoju województwa mazowieckiego do 2030 roku. Innowacyjne Mazowsze i w Planie zagospodarowania przestrzennego województwa mazowieckiego za obszary problemowe (ryc. 1), w których jedną z możliwości ożywienia gospodarczego jest rozwój turystyki, m.in. poprzez tworzenie produktów turystycznych.

W ramach prac nad nowymi produktami i ofertami przeanalizowano uwarunkowania do ich tworzenia, uwzględniając przede wszystkim obecność atrakcji turystycznych, a także potrzeb społecznych, oczekiwań współczesnego turysty i politykę samorządu województwa w zakresie rozwoju turystyki. Przy tworzeniu sieciowych produktów turystycznych istnieje możliwość wykorzystania ofert gospodarstw agroturystycznych. Agroturystyka przynosi wiele korzyści społecznych i przede wszystkim gospodarczych, co jest najistotniejsze w obszarach problemowych. Sprzyja aktywizacji i różnicowaniu działalności gospodarczej na obszarach wiejskich, jest źródłem dodatkowego dochodu, umożliwia zagospodarowanie niewykorzystanych dotychczas zasobów, w konsekwencji przyczynia się do wzrostu konkurencyjności gmin wiejskich. Punktem wyjścia do podjęcia tematu przez Biuro była chęć uzupełnienia o własne propozycje projektu Podnoszenie konkurencyjności turystycznej Mazowsza poprzez wdrażanie sieciowych produktów turystycznych, wykonanego przez Mazowiecką Regionalną Organizację Turystyczną w Warszawie na przestrzeni lat 2011-2013, będącego próbą wykreowania i skomercjalizowania produktów turystycznych w celu większego wykorzystania atrakcji turystycznych regionu i wyprowadzenia ruchu turystycznego z Warszawy w stronę peryferyjnych części regionu, również atrakcyjnych turystycznie. Wiedza o walorach przyrodniczych i kulturowych oraz zagospodarowaniu turystycznym do propozycji nowych ofert i produktów turystycznych pochodziła $\mathrm{z}$ wykonanych $\mathrm{w}$ poprzednich latach koncepcji szlaków turystycznych w pasmach przyrodniczo-kulturowych związanych z głównymi rzekami Mazowsza oraz analizy działalności gmin położonych w tych pasmach na rzecz rozwoju turystyki, a także monitorowania zmian zachodzących $w$ tej dziedzinie gospodarki jaką jest turystyka, m.in. na potrzeby oceny realizacji Strategii i Planu. Korzystano również z informacji uzyskanych od liderów 16 produktów turystycznych i podmiotów zainteresowanych włączeniem do tego typu działań. Analiza zasięgu realizacji ofert produktowych w ramach wykreowanych 16 sieciowych produktów wykazała, że ich rozkład przestrzenny koncentruje się głównie 


\section{Ryc.1. Obszary problemowe województwa mazowieckiego}

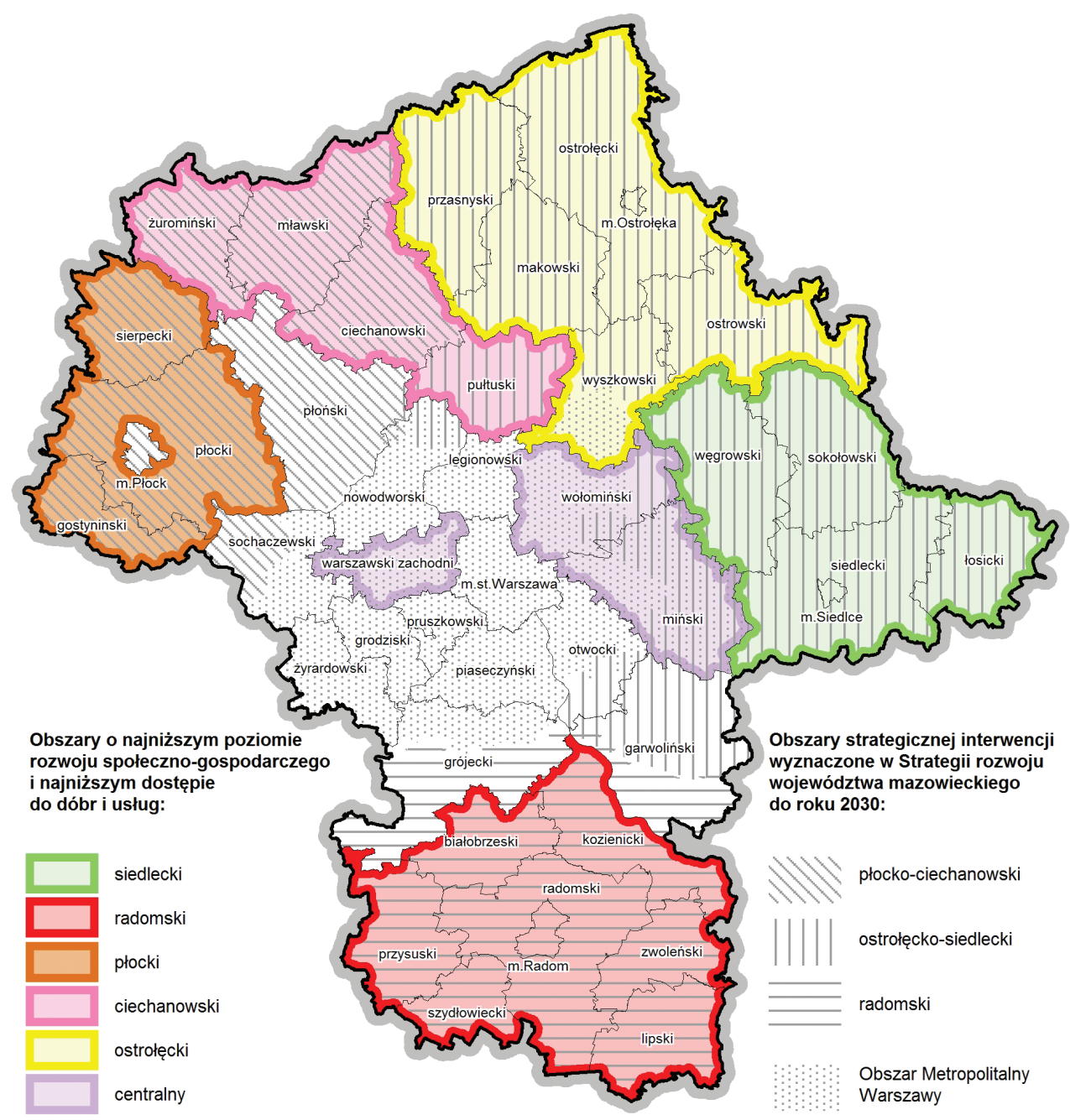

Źródło: Koncepcje sieciowych produktówturystycznych w subregionach województwa mazowieckiego, MAZOWSZE. Analizy i Studia, 7, 48, 2015

w środkowej części województwa. Produkty dobrze wykorzystują potencjał pasm turystyczno-kulturowych: części środkowej i zachodniej Wisły, Bugu i Liwca oraz Skrwy. Nie wykorzystują natomiast walorów pozostałych pasm rzecznych. Najwięcej ofert obejmuje część środkową województwa - obszar metropolitalny oraz subregion płocki i siedlecki. Niewiele ofert funkcjonuje w subregionach: ciechanowskim i radomskim przy zupełnym ich braku w subregionie ostrołęckim (ryc. 2). 


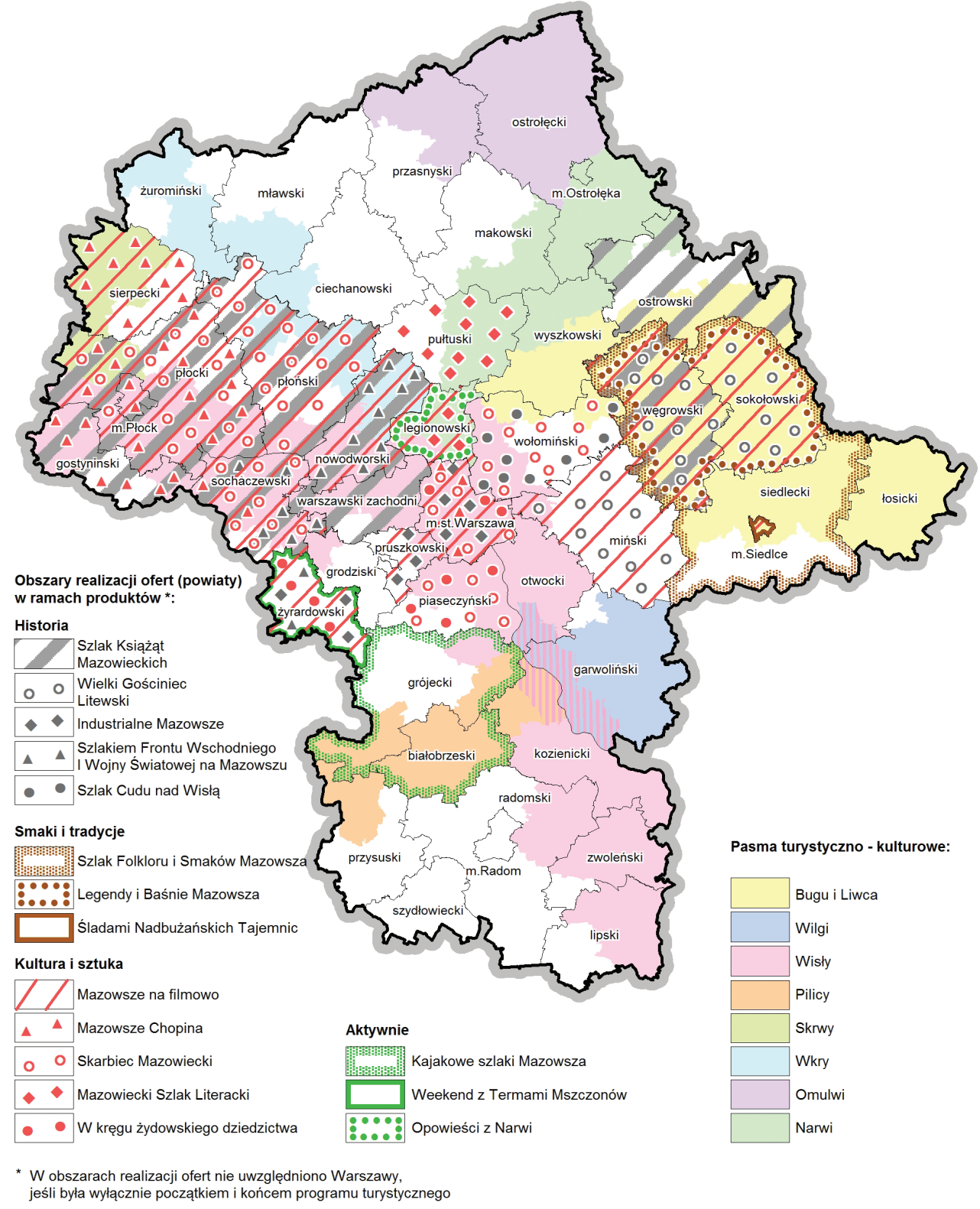

Źródło: Koncepcje sieciowych produktów turystycznych w subregionach województwa mazowieckiego, MAZOWSZE. Analizy i Studia, 7, 48, 2015 
Dwa istotne dla funkcjonowania województwa dokumenty: Plan zagospodarowania przestrzennego województwa mazowieckiego i Strategia rozwoju województwa mazowieckiego zawierają postulaty dotyczące poprawy sytuacji społeczno-gospodarczej obszarów peryferyjnych, problemowych, m.in. poprzez rozwój turystyki, w tym produktów turystycznych, które należy oprzeć na walorach środowiska przyrodniczego i kulturowego pasm przyrodniczo-kulturowych, walorach miast i tradycji historycznych oraz tradycji ludowych. Propozycje nowych produktów i ofert do istniejących produktów wykorzystujących potencjał turystyczny obszarów peryferyjnych zawarto w tabeli 2 . pochodzącej z opracowania Koncepcje sieciowych produktów turystycznych w subregionach województwa mazowieckiego, a zasięg przestrzenny wybranych produktów i ofert przedstawia rycina 3.

Poniżej przedstawiona jest krótka charakterystyka nowych produktów i wybranych najatrakcyjniejszych ofert z istniejących produktów z każdego subregionu województwa mazowieckiego.

Subregion siedlecki - Śladami broni V-2 i innych militariów

Proponowany nowy produkt turystyczny Śladami broni $V-2$ i innych militariów opiera się przede wszystkim na historii testowania rakiet V-2 (niemieckiej Wunderwaffe) we wschodniej Polsce i bogatym zbiorze związanych z tym eksponatów zgromadzonych w Muzeum Regionalnym w Siedlcach. W produkcie planuje się wykorzystanie też licznych obiektów, które są przystosowane do obecnie modnej turystyki militarnej, tj. strzelnice, muzeum techniki wojskowej czy miejsca do rozgrywek airsoftowych.

\section{Subregion radomski - Tradycje ludowe Radomszczyzny}

Tradycje ludowe Radomszczyzny to propozycja nowego produktu sieciowego w subregionie radomskim, opartego na dziedzictwie kultury ludowej krainy na pograniczu Mazowsza i Małopolski, w tym na tradycjach muzycznych zachowanych w mikroregionie kajockim (okolice Przysuchy). W budowaniu przedmiotowego produktu najistotniejsze będzie wykorzystanie zasobów i działalności naukowo-edukacyjnej Muzeum Wsi Radomskiej w Radomiu oraz jego oddziału - Muzeum im. Oskara Kolberga w Przysusze, a także cyklicznych imprez folklorystycznych m.in.: „Festiwalu Kapel, Śpiewaków, Zespołów Ludowych, Kół Gospodyń Wiejskich i Stowarzyszeń Ziemi Przysuskiej” w Odrzywole.

Subregion płocki - Wista - smak przygody

Wisła-smak przygody to propozycja nowego produktu sieciowego w subregionie płockim, którego podstawową atrakcją są walory Wisły w okolicach Płocka - jej ciekawe położenie geograficzne, bogactwo przyrodnicze i krajobrazowe wraz z Zalewem Włocławskim.

Zalew Włocławski z przyległymi terenami przyciąga pasjonatów różnych dyscyplin sportów wodnych i wędkarstwa, miłośników odpoczynku na łonie natury, zbierania grzybów, przejażdżek rowerowych i konnych oraz pieszych wycieczek. Doskonałym miejscem wypadowym dla wycieczek żeglarskich jest Płock. W tym pięknym zakątku zlokalizowana jest przystań żeglarska - Marina Murzynowo, w której można uprawiać różne formy czynnego wypoczynku, przede wszystkim sporty wodne. 
Tabela 2. Koncepcje sieciowych produktów turystycznych

\begin{tabular}{|c|c|}
\hline Produkt & Główna atrakcja \\
\hline \multicolumn{2}{|r|}{ SUBREGION SIEDLECKI } \\
\hline $\begin{array}{l}\text { Kajakiem wśród zamków, pałaców i dworów } \\
\text { nad Liwcem } \\
\text { (oferta w ramach istniejącego produktu } \\
\text { sieciowego Kajakowe Szlaki Mazowsza) }\end{array}$ & $\begin{array}{l}\text { atrakcyjność Liwca do uprawiania aktywnej turystyki wodnej } \\
\text { oraz walory przyrodniczo-krajobrazowe i kulturowe doliny rzeki - } \\
\text { szczególnie pozostałości średniowiecznych zamków, pałace i dwory }\end{array}$ \\
\hline Nie tylko bociany (nowy produkt) & $\begin{array}{l}\text { miejsca występowania rzadkich gatunków ptaków w dolinach rzek: } \\
\text { Bug i Liwiec }\end{array}$ \\
\hline $\begin{array}{l}\text { Śladami broni } V-2 \text { i innych militariów } \\
\text { (nowy produkt) }\end{array}$ & $\begin{array}{l}\text { pozostałości po testowaniu rakiet V-2 we wschodniej Polsce oraz } \\
\text { dostępne dla turystów obiekty militarne i wojskowe }\end{array}$ \\
\hline $\begin{array}{l}\text { Konno - ku pamięci Ludwika Maciąga } \\
\text { (nowy produkt) }\end{array}$ & $\begin{array}{l}\text { ośrodki jeździeckie i gospodarstwa agroturystyczne oraz } \\
\text { kultywowane w obszarze nadbużańskim tradycje kawaleryjskie }\end{array}$ \\
\hline \multicolumn{2}{|r|}{ SUBREGION RADOMSKI } \\
\hline $\begin{array}{l}\text { Radomski szlak architektury sakralnej } \\
\text { (oferta w ramach istniejącego } \\
\text { produktu sieciowego Skarbiec Mazowiecki) }\end{array}$ & zabytki architektury sakralnej, w tym sanktuaria \\
\hline $\begin{array}{l}\text { Radomski szlak literacki } \\
\text { (oferta w ramach istniejącego produktu } \\
\text { sieciowego Mazowiecki Szlak Literacki) }\end{array}$ & ośrodki kultury związane z wielkimi postaciami polskiej literatury \\
\hline $\begin{array}{l}\text { Tradycje ludowe Radomszczyzny } \\
\text { (nowy produkt) }\end{array}$ & $\begin{array}{l}\text { dziedzictwo kultury ludowej, w tym tradycyjna muzyka z regionu } \\
\text { przysuskiego }\end{array}$ \\
\hline \multicolumn{2}{|r|}{ SUBREGION PŁOCKI } \\
\hline $\begin{array}{l}\text { Skarbiec Płocki (oferta w ramach istniejącego } \\
\text { produktu sieciowego Skarbiec Mazowiecki) }\end{array}$ & $\begin{array}{l}\text { zabytkowe obiekty sakralne, w tym drewniane oraz miejsca } \\
\text { związane z życiem św. Faustyny }\end{array}$ \\
\hline $\begin{array}{l}\text { W kręgu żydowskiego dziedzictwa } \\
\text { w subregionie płockim (oferta w ramach } \\
\text { istniejącego produktu sieciowego W kręgu } \\
\text { żydowskiego dziedzictwa na Mazowszu) }\end{array}$ & pozostałości kultury żydowskiej \\
\hline $\begin{array}{l}\text { Kajakiem po Skrwie } \\
\text { (oferta w ramach istniejącego produktu } \\
\text { sieciowego Kajakowe Szlaki Mazowsza) }\end{array}$ & $\begin{array}{l}\text { atrakcyjność Skrwy do uprawiania aktywnej turystyki wodnej oraz } \\
\text { walory przyrodniczo-krajobrazowe i kulturowe doliny rzeki }\end{array}$ \\
\hline Wisła - smak przygody (nowy produkt) & $\begin{array}{l}\text { atrakcyjność geograficzna i przyrodnicza środkowej Wisły w okoli- } \\
\text { cach Płocka }\end{array}$ \\
\hline \multicolumn{2}{|c|}{ SUBREGION CIECHANOWSKI } \\
\hline $\begin{array}{l}\text { Dzień na Zamku Książąt Mazowieckich } \\
\text { w Ciechanowie } \\
\text { (oferta w ramach istniejącego produktu } \\
\text { sieciowego Szlak Książąt Mazowieckich) }\end{array}$ & $\begin{array}{l}\text { oferta edukacyjno-historyczna zamku w Ciechanowie w zakresie } \\
\text { dziejów Księstwa Mazowieckiego oraz kultury i obyczajów } \\
\text { średniowiecza }\end{array}$ \\
\hline $\begin{array}{l}\text { Ciechanowska podróż przez epoki literackie } \\
\text { (oferta w ramach istniejącego produktu } \\
\text { sieciowego Mazowiecki Szlak Literacki) }\end{array}$ & miejscowości związane z twórcami literatury polskiej \\
\hline $\begin{array}{l}\text { Spływ rzeka Wkra } \\
\text { (oferta w ramach istniejącego produktu sie- } \\
\text { ciowego Kajakowe Szlaki Mazowsza) }\end{array}$ & $\begin{array}{l}\text { atrakcyjność Wkry do uprawiania aktywnej turystyki wodnej oraz } \\
\text { walory przyrodniczo-krajobrazowe i kulturowe doliny rzeki }\end{array}$ \\
\hline \multicolumn{2}{|r|}{ SUBREGION OSTROŁĘCKI } \\
\hline $\begin{array}{l}\text { Kajakiem po Omulwi } \\
\text { (oferta w ramach istniejącego produktu } \\
\text { sieciowego Kajakowe Szlaki Mazowsza) }\end{array}$ & $\begin{array}{l}\text { atrakcyjność Omulwi do uprawiania aktywnej turystyki wodnej oraz } \\
\text { walory przyrodniczo-krajobrazowe i kulturowe doliny rzeki }\end{array}$ \\
\hline $\begin{array}{l}\text { Tradycja kurpiowska - przekazem dla pokoleń } \\
\text { (nowy produkt) }\end{array}$ & kultura ludowa kurpiowskiego regionu etnograficznego \\
\hline $\begin{array}{l}\text { Leśne ostoje Puszczy Kurpiowskiej (nowy } \\
\text { produkt) }\end{array}$ & pozostałości dawnej Puszczy Kurpiowskiej \\
\hline
\end{tabular}

Źródło: Koncepcje sieciowych produktów turystycznych w subregionach województwa mazowieckiego,

MAZOWSZE. Analizy i Studia, 7, 48, 2015 
Ryc. 3. Zasięg przestrzenny proponowanych produktów turystycznych

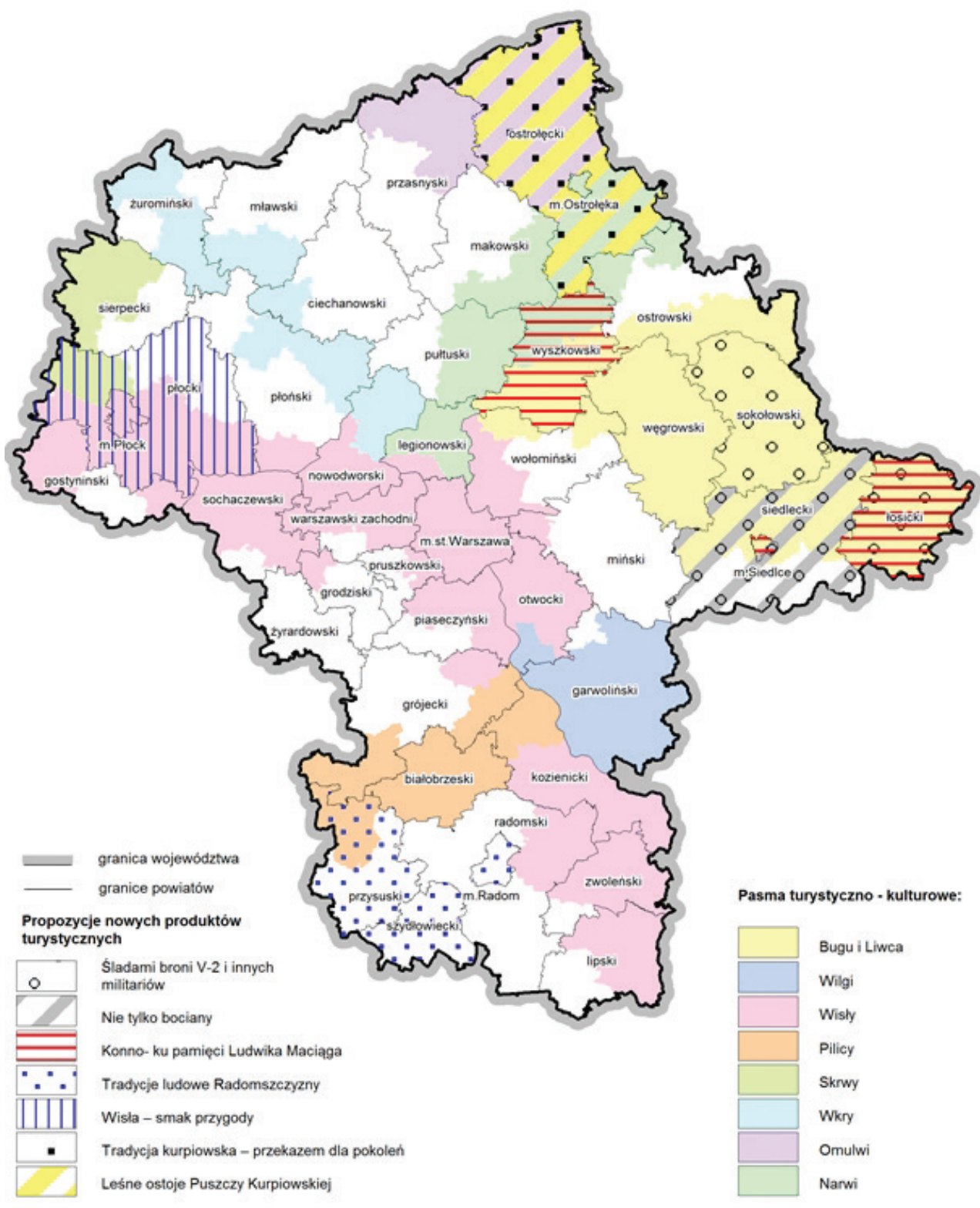

Źródło: D. Oleszczuk na podstawie Koncepcji sieciowych produktów turystycznych w subregionach województwa mazowieckiego, MAZOWSZE. Analizy i Studia, 7,48, 2015 
Do dodatkowych atrakcji, które można wykorzystać do tworzenia ofert turystycznych w ramach produktu Wisła - smak przygody należą: pokazy sportów motorowodnych, narciarstwa wodnego i wakeboardingu w wykonaniu zawodników zrzeszonych w Polskim Związku Motorowodnym i Narciarstwa Wodnego, a także pokazy bezpiecznego zachowania nad wodą w wykonaniu Rejonowego Płockiego Wodnego Ochotniczego Pogotowia Ratunkowego. Niezwykłych wrażeń artystycznych mogą dostarczyć też koncerty szant i piosenek turystycznych.

Subregion ciechanowski - Ciechanowska podróż przez epoki literackie

Ciechanowska podróż przez epoki literackie jest nową ofertą w ramach wykreowanego pod patronatem Mazowieckiej Regionalnej Organizacji Turystycznej produktu turystycznego Mazowiecki Szlak Literacki. Głównymi atrakcjami proponowanej oferty są miejscowości subregionu ciechanowskiego związane z twórcami literatury polskiej: poetą epoki romantyzmu - Zygmuntem Krasińskim, pozytywistycznym pisarzem i publicystą - Aleksandrem Świętochowskim oraz poetką i nowelistką okresu realizmu - Marią Konopnicką. W ramach oferty przewiduje się zapoznanie turystów z walorami kulturowymi i przyrodniczymi w miejscowościach: Krasne, Opinogóra, Gołotczyzna i Ciechanów.

\section{Subregion ostrołęcki - Tradycja kurpiowska - przekazem dla pokoleń}

Podstawową atrakcją nowego produktu turystycznego Tradycja kurpiowska - przekazem dla pokoleń jest możliwość zetknięcia się z niepowtarzalną kulturą ludową kurpiowskiego regionu etnograficznego - Puszczy Kurpiowskiej (Zielonej). Kurpiowszczyzna to jeden z najciekawszych etnograficznie regionów w kraju. Szczególnie bogata i wyróżniająca się jest sztuka ludowa Kurpiów, która znalazła swój wyraz przede wszystkim w budownictwie, zdobnictwie, rzeźbiarstwie, tkactwie, wycinankarstwie, jak również w stroju. Na terenie Puszczy Zielonej do dziś działa wielu twórców ludowych, którzy zajmują się pielęgnowaniem i rozwijaniem kultury ludowej. Twórcy oferuja m.in.: wycinanki, kwiaty z bibuły, palmy, pisanki, ozdoby choinkowe, rzeźby (świątki, zabawki), koronki, hafty, wyroby tkane, pieczywo obrzędowe, wyroby z bursztynu (kolie, różańce, wisiorki, zapinki i inne), wyroby z wikliny, sitowia i słomy oraz korzenia sosny i jałowca, naczynia ceramiczne (garnki, dzbanki, misy), wyroby kowalstwa, świece woskowe czy potrawy regionalne. Rokrocznie w czerwcu, począwszy od 2001 r., na terenie Zagrody Kurpiowskiej w Kadzidle (Oddział Muzeum Kultury Kurpiowskiej w Ostrołęce), biorą oni udział w warsztatach etnograficznych pod nazwą Ginace Zawody. Kultywowane są dawne zwyczaje, urozmaicone pieśniami i tańcami przy muzyce granej na instrumentach, w tym zwłaszcza na charakterystycznej dla Kurpi harmonii pedałowej. Ponadto nadal używana jest gwara i swoisty kurpiowski strój ludowy, który zobaczyć można nie tylko przy okazji festynów, ale również w czasie świąt, czy nawet w zwykłe niedziele podczas mszy świętych. Dodatkowymi walorami Puszczy Zielonej, które można wykorzystać do uzupełnienia oferty w ramach produktu Tradycja kurpiowska - przekazem dla pokoleń, są cenne obiekty zabytkowe, głównie sakralne oraz mieszkalne, w tym drewniane. Na terenie Puszczy Zielonej można zobaczyć wiele charakterystycznych dla tego obszaru drewnianych chałup budowanych w stylu kurpiowskim. Stawiano je zawsze szczytem do drogi, w związku z tym szczyty 
domów miały dekoracyjny charakter. Kilka charakterystycznych obiektów budownictwa drewnianego związanego z osadnictwem na Kurpiach zgromadzonych zostało w Zagrodzie Kurpiowskiej w Kadzidle. Wybierając się na Kurpie warto wziąć pod uwagę terminy odbywających się tu cyklicznych imprez folklorystycznych, m.in. są to:

Palma Kurpiowska (w Niedzielę Palmową-tydzień przed Wielkanocą) w miejscowości Łyse - jedna z najbarwniejszych w kraju procesji z palmami wielkanocnymi, z podsumowaniem konkursu palm, prezentacjami zespołów folklorystycznych oraz kiermaszem sztuki ludowej;

Wesele Kurpiowskie (w trzecią niedzielę czerwca) w Zagrodzie Kurpiowskiej w Kadzidle - widowisko z inscenizacją tradycyjnego obrzędu ślubnego i zwyczajów weselnych na Kurpiach (często jest to autentyczny ślub), które poprzedzają „Rajby” (swatanie i zaręczyny); podczas imprezy uczestnicy stają się "gośćmi weselnymi", mogą skosztować potraw regionalnych, a nawet zatańczyć z panną młoda, odbywa się przy tym kiermasz sztuki ludowej;

Miodobranie Kurpiowskie (w ostatnią niedzielę sierpnia) w kompleksie sportoworekreacyjnym „Kurpiowska Kraina” w miejscowości Wykrot (gmina Myszyniec) - impreza ogólnopolska, widowisko zakończenia miodobrania w puszczy, występy zespołów regionalnych, wystawy i kiermasze twórczości ludowej, możliwość nabycia miodu od pszczelarzy i wypieków z miodem od gospodyń kurpiowskich.

\section{Podsumowanie}

Nowe trendy $\mathrm{w}$ turystyce wiążą się $\mathrm{z}$ rosnącym zapotrzebowaniem na wypoczynek krótki, ale z maksymalną intensywnością wrażeń. Realizacja tych potrzeb jest możliwa poprzez kompleksowe, wyspecjalizowane oferty funkcjonujące $\mathrm{w}$ ramach innowacyjnych sieciowych produktów turystycznych. W województwie mazowieckim walory turystyczne w postaci dziedzictwa kulturowego i przyrodniczego, zagospodarowanie turystyczne, dobra dostępność komunikacyjna oraz wysoki standard bazy noclegowej stanowią fundament tworzenia niepowtarzalnych, atrakcyjnych produktów turystycznych nastawionych zarówno na turystów krajowych, jak i zagranicznych. Dotychczasowe wykorzystywanie potencjału turystycznego regionu jest nierównomierne, z tego względu istnieje potrzeba integracji głównych, najbardziej znanych atrakcji województwa, głównie Warszawy, z walorami obszarów niedostatecznie wykorzystanych. Wyrównanie tej dysproporcji umożliwi kreowanie i promowanie sieciowych produktów turystycznych, zwłaszcza markowych. Właściwości takich produktów przyczynią się do wykształcenie pozytywnego, atrakcyjnego wizerunku nie tylko samych produktów, ale i całego regionu, co może mieć istotny wpływ na decyzje turystów dotyczące miejsca i formy wypoczynku.

W polityce rozwoju regionu jaką prowadzi samorząd województwa (zawartej w dokumentach strategicznych, planistycznych i programowych) wspieranie tworzenia produktów turystycznych stanowi również jeden z jej ważnych elementów. Proces ich tworzenia jest szczególnym działaniem w sferze gospodarki ze względu na konieczność współpracy podmiotów gospodarczych, chcących osiągnąć korzyści materialne z instytucjami publicznymi 
nastawionymi na zyski niematerialne. Jednakże taka współpraca, przynosząca wiele konfliktów i problemów, może zaowocować kreacją produktów markowych, innowacyjnych i konkurencyjnych.

Pierwsze działania na rzecz tworzenia sieciowych produktów turystycznych w regionie podjęły organizacje pozarządowe, w tym lokalne organizacje turystyczne. Jednak ich działalność w tym zakresie bardziej usystematyzowała Mazowiecka Regionalna Organizacja Turystyczna, czego efektem była komercjalizacja w 2013 r. 16 markowych sieciowych produktów turystycznych, z których większość bazuje na dziedzictwie historycznym i kulturowym regionu (Szlak Ksiażąt Mazowieckich, Wielki Gościniec Litewski, Industrialne Mazowsze, Szlakiem Frontu Wschodniego I Wojny Światowej, Szlak Cudu nad Wisła, Szlak folkloru i smaków Mazowsza, Legendy i Baśnie Mazowsza, Śladami Nadbużańskich Tajemnic, Mazowsze na filmowo, Mazowsze Chopina, Skarbiec Mazowiecki, Mazowiecki Szlak Literacki, W kręgu żydowskiego dziedzictwa na Mazowszu), a część na zasobach przyrodniczych (Kajakowe Szlaki Mazowsza, Weekend z Termami Mszczonów, Opowieści z Narwi). Powiązanie pojedynczych atrakcji turystycznych w postać zintegrowanych i innowacyjnych ofert w ramach produktów turystycznych może podnieść atrakcyjność województwa, wykreować jego turystyczną markę, a także przyczynić się do wzrostu efektywności ekonomicznej działalności w sferze turystyki. Ponadto powiązanie pojedynczych produktów i usług w produkty sieciowe może przyczynić się do bardziej efektywnego wykorzystania zasobów Mazowsza poprzez wyprowadzenie ruchu turystycznego, dotychczas koncentrującego się głównie w Warszawie, do innych części regionu. Sieciowe produkty turystyczne mogą przyczynić się do rozwoju społeczno-gospodarczego regionu, zwłaszcza jego peryferyjnych regionów, gdyż przyczyniają się do: wydłużenia sezonu turystycznego i czasu pobytu turystów, zwiększenia popytu na lokalne wyroby i usługi oraz wzrost produkcji drobnej przedsiębiorczości. Wpływają także na zacieśnienie współpracy między podmiotami w ramach funkcjonujących ofert produktowych.

Należy jednak podkreślić, że rozwój produktów turystycznych, ich komercjalizacja i sprzedaż ofert turystom wymaga podjęcia szeregu działań m.in. ze strony samorządu województwa. Przede wszystkim:

- rozbudowy i modernizacji infrastruktury turystycznej i paraturystycznej, infrastruktury technicznej - szczególnie komunikacyjnej i teleinformatycznej,

- wsparcia organizacyjnego w zakresie planowania i rozwoju produktów takich instytucji jak MROT,

- certyfikowania produktów wyróżniających się,

- promocji poprzez wszystkie dostępne media,

- współpracy z sąsiednimi samorządami, gdyż oferty często wychodzą poza obszar województwa i co najważniejsze,

- wsparcia finansowego w ramach różnych instrumentów województwa.

Funkcjonowanie produktów turystycznych, powinno być monitorowane i oceniane pod względem wpływu na wielkość i rozkład przestrzenny ruchu turystycznego na Mazowszu. 


\section{Akty prawne i dokumenty}

Plan zagospodarowania przestrzennego województwa mazowieckiego, Uchwała nr 180/14 Sejmiku Województwa Mazowieckiego z dnia 7 lipca 2014 r.

Strategia Rozwoju Województwa Mazowieckiego do 2030 roku Innowacyjne Mazowsze, Uchwała nr 158/13 Sejmiku Województwa Mazowieckiego z dnia 28 października 2013 r.

Strategia rozwoju trystyki województwa mazowieckiego na lata 2007-2013, Uchwała nr 52/08 Sejmiku Województwa Mazowieckiego z dnia 31 marca 2008 r.

Strategia rozwoju turystyki w województwie mazowieckim na lata 2014-2020, Uchwała nr 81/15 Sejmiku Województwa Mazowieckiego z dnia 8 września 2015 r.

Ustawa z dnia 27 marca 2003 r. o planowaniu i zagospodarowaniu przestrzennym (tekst jednolity Dz.U. z 2015 r., poz. 199, 443, 774).

Ustawa z dnia 25 czerwca 1999 r. o Polskiej Organizacji Turystycznej (tekst jednolity Dz.U. z 2008 r., nr 227, poz.1505).

Ustawa z dnia 5 czerwca 1998 r. o samorządzie województwa (tekst jednolity Dz. U. z 2013 r., poz. 596 z późn. zm.).

Wojewódzki Program opieki nad zabytkami na lata 2006-2009, Uchwała nr 226/05 Sejmiku Województwa Mazowieckiego z dnia 19 grudnia 2005 r.

Wojewódzki Program opieki nad zabytkami na lata 2012-2015, Uchwała nr 42/12 Sejmiku Województwa Mazowieckiego z dnia 12 marca 2012 r.

\section{Literatura}

Gadomska U. (red), Dymna B., Gurbała M. i in., 2015, Koncepcje sieciowych produktów turystycznych w subregionach województwa mazowieckiego, MAZOWSZE. Analizy i Studia, 7, 48, Mazowieckie Biuro Planowania Regionalnego, Warszawa.

Kachniewska M., 2015, Model tworzenia sieciowego produktu turystycznego, Mazowiecka Regionalna Organizacja Turystyczna, Warszawa.

Katalog Produktowy Mazowsze Lato-Zima 2013-2014, 2013, Mazowiecka Regionalna Organizacja Turystyczna, Warszawa.

Łazarek R., 2004, Ekonomika Turystyki, Wyższa Szkoła Ekonomiczna, Warszawa. 
Majewska I., Telniuk T., Broma i in., 2008, Program rozwoju produktów turystyki aktywnej i kulturowej w województwie mazowieckim, Polska Agencja Rozwoju Turystyki S.A., Warszawa.

Program rozwoju sieciowych produktów turystycznych województwa mazowieckiego, 2011, Mazowiecka Regionalna Organizacja Turystyczna, Warszawa.

Sieciowy produkt turystyczny na terenie LGD-Szanse rozwoju turystyki wiejskiej w świetle badań preferencji turystycznych mieszkańców Lublina, 2012, Biuletyn 9, 1, Lokalna Grupa Działania „Kraina wokół Lublina”, Lublin. 


\section{Creation of network tourist products in Mazowieckie Voivodeship}

\section{ABSTRACT}

The purpose of this article is to define the terms "tourist product" and "network tourist product", to describe the history of their creation and commercialization in Mazovia, and to present proposals of new such products in the peripheral areas of the Mazovia region. There are big disparities in the extent to which touristic potential is exploited in Mazovia. Networked travel products, especially branded ones, would enable the region's well-known attractions to be integrated with the touristic assets of areas not yet exploited. Supporting the creation and promotion of tourist products is one of the elements of the regional development policy pursued by the regional government of Mazovia, as confirmed by the strategic, planning and program documents of the region. The Spatial Development Plan of Mazovia and the Development Strategy of Mazovia 2030, Innovative Mazovia indicate the potential for socio-economic revival of the Siedlce, Radom, Płock, Ciechanów and Ostrołęka subregions (identified as problem areas of Mazovia) through the development of tourism, including the creation and commercialization of network tourist products. The Mazovian Regional Tourist Organization (MROT) has systematically worked towards the creation, promotion and functioning of network tourist products. The article presents the process of creating tourist products in 2008-2017 and the problems related to their implementation.

The article also contains a brief description of the not yet exploited cultural and natural values in the peripheral areas of the region, where the tourist products proposed by the Mazovian Office of Regional Planning can be based. Making use of opportunities for the development of tourist products, however, requires a number of actions to be undertaken by the regional government, including the development of technical infrastructure (especially communication and information technology), financial assistance, promotion of tourist products and cooperation with the governments of neighboring regions.

Key words: tourist product, network tourist product, strategic, planning and programming documents of the Mazovia region

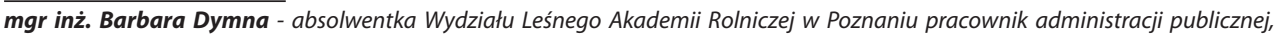
kontakt: Mazowieckie Biuro Planowania Regionalnego w Warszawie, 19/21, 08-110 Siedlce, e-mail:bdymna@mbpr.pl

Barbara Dymna M. Eng - a graduate of the Forestry Faculty of the Agricultural Universty of Poznan, public administration employee, Mazowian Office of Regional Development in Warsaw, OT Siedlce Branch Office in Siedlce, ul. Pułaskiego, contact: Mazowieckie Biuro Planowania Regionalnego w Warszawie, 19/21, 08-110 Siedlce, e-mail:bdymna@mbpr.pl 